\title{
A construção do feminino no cinema de Pedro Almodóvar*
}

\author{
Paloma Coelho**
}

\begin{abstract}
Resumo
Este artigo analisa a produção técnica da feminilidade empreendida pelo cinema de Almodóvar a partir da elaboração de um "universo feminino" que lhe rendeu a fama de "diretor de mulheres". Propõe-se uma reflexão sobre o universo simbólico e as formulações discursivas que podem tanto ressignificar subjetividades, como trazer à tona alguns cânones ou ressonâncias desses discursos. Argumenta-se que essas narrativas, como um contradiscurso, reincidem nos padrões visuais hegemônicos e revelam, ainda que implicitamente, a noção de desigualdade sexual na qual se baseiam.
\end{abstract}

Palauras-chave: Gênero, Subjetividade, Diferença Sexual, Cinema, Almodóvar.

* Recebido em19 de fevereiro de 2018, aceito em 29 de junho de 2020.

**Pós-doutoranda no Programa de Pós-Graduação em Saúde Coletiva da Fundação Oswaldo Cruz (Fiocruz Minas), Belo Horizonte, MG, Brasil. palomafcs@gmail.com/ https://orcid.org/0000-0001-9553-0036 
The Construction of the Feminine in Pedro Almodovar's Cinema

\begin{abstract}
This article analyses the technical production of femininity in the films of Almodovar through the elaboration of a "feminine universe" that led to his fame as a "director of women". It proposes a reflection on the symbolic universe and discursive formulations that can both resignify subjectivities and bring to light some canons or resonances of these discourses. It is argued that these narratives, as a counter-discourse, fall back on hegemonic visual standards and reveal, although implicitly, the notion of sexual inequality on which they are based.
\end{abstract}

Keywords: Gender, Subjectivity, Sexual difference, Cinema, Almodóvar. 


\section{Introdução}

O filme, entendido como um texto social que perscruta o domínio do simbólico, mas também o constitui ao se conectar com outros textos, é dotado de camadas de significados que transcendem os discursos intencionados, por mais diretos e explícitos que pareçam aos olhos do espectador. São conotações subjacentes que compõem a poética dessas imagens, cujo estatuto é desvelado quando se decompõem os princípios gerais de sua construção. Em outras palavras, sendo a narrativa uma história que se conta, mas também a maneira com que é contada, a imagem cinematográfica é uma espécie de linguagem cifrada, em que a ordenação dos signos presentes no visível, mas também no que se encontra latente, naquilo que não se diz, porém é ressonante, engendra os sentidos, os discursos e até mesmo os contradiscursos (Rancière, 2005).

Tal qual uma moldura, que comporta o que está dentro e fora do quadro ou do enquadramento, o filme é a junção do que a imagem torna visível, mas também de uma "ausência recuperável", que se manifesta e se faz presente naquilo que escapa às intenções do diretor, nos mitos que retornam em outras roupagens, nas zonas de silêncio que tornam eloquentes os contradiscursos, como metáboles, a repetição de uma mesma ideia em outros termos (Cañizal, 1996). Partindo da ideia de que "o real precisa ser ficcionado para ser pensado" (Rancière, 2005:58), a análise que se segue corresponde a uma imersão nessas ficções, ou no universo simbólico das imagens construídas por Almodóvar, em que as formulações discursivas podem tanto ressignificar subjetividades, como trazer à tona alguns cânones ou ressonâncias desses discursos.

Em um primeiro momento, problematizam-se os códigos visuais utilizados por Almodóvar na construção fílmica do gênero em relação aos elementos geralmente apontados como transgressores, começando pela imagem de "diretor de mulheres". Em seguida, discutem-se as narrativas dos gêneros contidas na filmografia de Almodóvar com ênfase na construção do feminino, demonstrando como essas imagens podem constituir contradiscursos que, muitas vezes, escapam às intenções do diretor, mas revelam, ainda que implicitamente, a noção de desigualdade sexual na qual se baseiam. Compreende-se, assim, que as formulações discursivas de um filme e, mais ainda, de uma filmografia vista em conjunto, não são unívocas, mas encobrem várias camadas de significado muitas vezes dissonantes, evidenciando a complexidade de uma obra.

\section{Os homens também choram, mas as mulheres choram melhor}

A incursão de Almodóvar no "universo feminino" fez com que ele se tornasse conhecido por construir um novo olhar sobre as mulheres no cinema, o que, certamente, corresponde a uma importante mudança de perspectiva em relação aos padrões visuais clássicos. A recorrência dessa temática e a repetição de personagens femininos com características tão singulares deram origem, consequentemente, a um novo modelo de feminilidade, o das Almodovar's girls ou das Chicas de Almodóvar. O diretor é responsável, assim, pela produção de uma subjetividade feminina que, se por um lado, reivindica a liberdade individual sobre o seu destino, seus corpos e sua sexualidade, por outro mantém a figura das mulheres confinada em um espaço simbólico ainda sustentado pelo pensamento da diferença sexual, pela repaginação de alguns mitos reproduzidos historicamente.

Em 1995, durante uma visita ao Brasil para o lançamento de A flor do meu segredo (1995), Almodóvar foi questionado sobre um artigo assinado pelo crítico espanhol Guillermo Cabrera Infante, que dizia: "Pedro Almodóvar é agora o melhor inventor de mulheres do cinema. Uma espécie de Adão com costelas suficientes para criar várias delas". O entrevistador pergunta, então, se o diretor se sente um criador de mulheres, ao que ele responde:

A origem dos meus personagens femininos está na realidade. Eu sou um grande observador da vida das mulheres. Um observador quase como um entomólogo observa os insetos. Não quero comparar as mulheres aos insetos, mas com uma mistura de curiosidade e fascinação por seus mecanismos, que são quase os mesmos mecanismos que os nossos. Não pensem que nós homens sejamos tão diferentes. Somos suficientemente distintos para nos interessarmos pelas mulheres, mas o que acontece é que as mulheres são muito mais interessantes em suas reações, na maneira como reagem (Roda Viva, 1995). 
Como se vê, Almodóvar não apenas se coloca como um "diretor de mulheres", tal qual a mídia lhe classifica, como também se afirma como um reprodutor do universo feminino através de uma lente realista, a partir do que ele extrai em seu contexto social. Essa visão é compartilhada pela pesquisadora María Antonia García de León ${ }^{1}$, para quem o feminino é retratado em Almodóvar por um olhar antropológico: "Gosto muito da antropologia das mulheres em Almodóvar porque ele realmente tem muito bom ouvido. Nisso Almodóvar não tem nada de bobo. [...] Almodóvar, antropólogo de ouvido".

Ao reposicionar as mulheres para o centro das narrativas, lhes dando o protagonismo que até então não se via em grande parte dos filmes, Almodóvar cria também um quadro imagético das mulheres tão revestido de naturalismo que passa a ser visto como um retrato real da subjetividade feminina; "Em Mulheres à beira de um ataque de nervos (1988),por exemplo, quem duvida, são bobagens e tal, mas são bobagens genuínas de uma garota, você acredita. E ele trata muito bem as mulheres nesse filme porque é antropólogo e sabe muito bem" (María Antonia García de León). A capacidade de convencimento dessa imagem se deve ao cuidado do diretor em elaborar um conjunto de referências culturalmente relacionadas às mulheres para facilitar a familiaridade do público, o que faz dele um "conhecedor do universo feminino", como é comumente citado.

Esse estilo em que o diretor se apropria de códigos do cinema clássico, mas também personaliza por meio de alguns deslocamentos, abarca a instituição de um novo modelo de feminilidade, com características que vão sendo reiteradas em cada filme. As "garotas de Almodóvar" passam a ser reconhecidas pela força, capacidade de sobrevivência e superação, mas também pela solidariedade e cumplicidade entre as mulheres, pela histeria e descontrole emocional, pela dependência afetiva (tanto dos homens, como das mulheres, no caso das personagens lésbicas) e pela habilidade para fingir ou representar como estratégia de sobrevivência. A eleição da temática feminina como eixo dramático central em alguns filmes de Almodóvar se deve, segundo ele, à associação das mulheres ao sentimentalismo exacerbado e às consequências da expressão das emoções levadas por elas ao limite, como a loucura, a histeria e as lágrimas: "Como dizia Raphael, 'os homens também choram', mas eu creio que as mulheres choram melhor. Essa é a razão de Mulheres à beira de um ataque de nervos e não de Homens à beira de um ataque de nervos" (Almodóvar, 2011c:126).

Para o diretor, essa predileção por retratar os dramas femininos advém de um comportamento social das mulheres, "mais espetacular" do que o dos homens no que diz respeito à vivência das emoções:

Antes dos anos setenta, se uma garota abandonava um garoto, o rapaz era obrigado a se tornar um herói, através de uma aventura pessoal ou fazendo algo pela humanidade, descobrindo uma vacina ou algo assim. Nos anos setenta, com o surgimento nas telas do anti-herói com barba de semanas e traumatizado por alguma guerra ou casamento fracassado, se, além disso, sua namorada lhe deixasse, o garoto se comportava de um modo terrivelmente realista e não tentava fazer nada pela humanidade. Ao contrário, abandonava seu trabalho e o banheiro, $e$ começava a encher a cara além da conta. E, movido pela espontaneidade própria do álcool, dedicava toda a sua energia a fazer escândalo para a sua família, seus colegas de trabalho $e$, finalmente, repudiado por todo mundo, aos garçons, únicos seres condenados tradicionalmente pelos roteiros a escutar impunemente até que lhe dêem um Oscar ao garoto pelo bem que lhe caem as olheiras e a barba. Não vou negar que nós garotos sofremos e que a solidão nos pesa tanto como para uma feminista, mas a quem interessa hoje em dia fazer um filme sobre o tema? A mim, particularmente, não. As garotas, essas sim sabem se comportar quando seu namorado as abandona. Não conhecem o pudor, nem o senso do ridículo, nem essa coisa horrenda que antes se chamava amor próprio. Suas reações estão cheias de registros. A mulher sabe que precisa de amor para continuar respirando e está disposta a defendê-lo como seja. Porque nessa eterna guerra todas as armas são permitidas. Se uma garota é deixada por outra pelo seu amante, não tem problema em sair pela rua, verificar quem é 'a outra', atirar sua rival em um precipício, tentar virar sua amiga para que a rival tenha terríveis sentimentos de culpa e lhe conte piadas íntimas de seu amante comum (Almodóvar, 2011c:126).

\footnotetext{
${ }^{1}$ Dados de entrevista. Pesquisa de campo realizada em Madri, em 3 nov. 2014.
} 
Ainda que Almodóvar desconstrua alguns estereótipos de gênero, nota-se que em relação à subjetividade feminina e masculina a noção de diferença sexual permanece como base para estabelecer as condutas de homens e mulheres. Quase sem distinguir ficção e realidade, o diretor parece transpor para as experiências da vida social as imagens cristalizadas no cinema, diluindo as fronteiras entre o que se passa dentro $e$ fora das telas; em sua fala, os sentimentos $e$ comportamentos dos filmes e da vida real se confundem. As mulheres continuam associadas ao amor, à dependência afetiva e ao descontrole emocional quando o relacionamento é rompido, quando é abandonada pelo ser amado.

Os homens, ao contrário, são vistos como mais racionais e seguros de si, dotados de equilíbrio e mais contidos até mesmo quando se desestruturam após o fim de uma relação. A imagem da mulher feminista, porém, contradiz o comportamento exacerbado das demais mulheres, outro estereótipo reafirmado. O diretor associa a solidão de uma feminista à dos homens, como se o feminismo extraísse das mulheres o que elas teriam de "mais feminino". Em outras palavras, as feministas seriam "menos mulheres", como fica claro, por exemplo, na personagem Paulina em Mulheres à beira de um ataque de nervos, uma advogada feminista retratada como racional, insensivel e mal-humorada.

A solidariedade entre as mulheres é uma característica bastante recorrente em seus filmes que abordam o feminino. Questionado em uma entrevista se não haveria solidariedade masculina, o diretor diz que não costuma notá-la de maneira significativa entre os homens e, caso houvesse, seria grotesco, difícil de imaginar, exceto entre os religiosos, que possuem como prática o auxílio mútuo e a organização coletiva (Strauss, 2008). Já a solidariedade entre as mulheres se revela com frequência em momentos de crise. O tema da mulher em crise, aliás, é outra imagem muito explorada por ele. Ao contrário dos modelos de feminilidade cristalizados pelo cinema hollywoodiano, as mulheres de Almodóvar em sua maioria, ainda que em crise, não são infantilizadas, passivas e inocentes. Antes, são fortes, determinadas e com grande capacidade de superação, embora algumas personagens fujam desse padrão: Candela em Mulheres à beira de um ataque de nervos e Kika no filme homônimo são mulheres ingênuas, sonhadoras e menos maduras, lembrando bastante a personagem Cabiria, de Fellini, em Noites de Cabiria (1957), uma das influências do neorrealismo italiano em seu cinema.

Gradativamente, a figura da mulher histérica, excessivamente nervosa e exaltada do início da carreira dá lugar a uma imagem mais apaziguada, marcada pela dor da perda e pelo sofrimento cotidiano. As mulheres de Tudo sobre minha mãe (1999) e de Volver (2006) são expressão dessa mudança, com a inclusão de outro tema também muito associado ao feminino em seus filmes, que é o da maternidade, representado por Manuela, Raimunda e Irene, respectivamente. A mulher em crise, o abandono e a solidão se somam à capacidade de fingir e de atuar - muitas vezes com a mentira - como características próprias do feminino, uma de suas estratégias de sobrevivência. Tais qualidades constituem a imagem que o diretor construiu a partir de seu ponto de vista sobre as mulheres com as quais conviveu ao longo da vida, como ele conta a respeito do processo de criação de Tudo sobre minha mãe:

Minha ideia principal era fazer um filme sobre a capacidade de atuar de determinadas pessoas que não são atrizes. De menino lembro ter visto essa qualidade nas mulheres da minha família. Fingiam mais e melhor que os homens. E, na base de mentiras, conseguiam evitar mais de uma tragédia. Há 40 anos, quando eu vivia ali, La Mancha era uma zona árida e machista em cujas famílias o homem reinava em sua poltrona de couro brilhante. Enquanto isso, as mulheres eram quem realmente resolvia os problemas, em silêncio, tendo muitas vezes que mentir (será essa a razão pela qual García Lorca dizia que Espanha sempre havia sido um país de boas atrizes?). Contra esse machismo manchego de que eu me recordo (talvez agigantado) da minha infância, as mulheres fingiam, mentiam, ocultavam $e$, desse modo, permitiam que a vida fluísse e se desenvolvesse, sem que os homens soubessem, nem impedissem (além de vital era espetacular. O primeiro espetáculo que vi foi o de várias mulheres falando nos quintais). Não sabia, mas esse ia ser um dos temas de meu filme número 13 , a capacidade da mulher para fingir. E a maternidade ferida. E a solidariedade espontânea entre as mulheres, mais uma vez (Almodóvar, 2011d:252). 
A capacidade de fingir, mentir e manipular como meio de sobrevivência, e que Almodóvar costuma abordar como atributo feminino, não é problematizada em seus filmes no sentido de que as mulheres utilizam essas armas sutis porque não dispõem ou não lhes permitem outras formas de poder, ainda mais em uma sociedade tradicionalmente conservadora e machista como La Mancha, cenário de algumas de suas películas, como Volver.

A solidão masculina é também retratada em Fale com ela (2002), porém, considerando toda a filmografia de Almodóvar, observa-se que não se trata de uma característica associada ao masculino, como ocorre com o feminino. Em seus filmes que ele e a imprensa classificam como femininos, o diretor quase sempre se refere à solidão e ao abandono como uma das temáticas abordadas. Sobre A flor do meu segredo, ele afirma haver pensado, primeiramente, no título Como vaca sin cincerro, expressão que no espanhol denota uma pessoa livre, sem controle e sem dono, mas também sem rumo, o que serviria de metáfora para falar da solidão feminina (Roda Viva, 1995). Essa definição poderia perfeitamente ser atribuída a outras películas, como Que fiz eu para merecer isso?(1984), Mulheres à beira de um ataque de nervos, De salto alto (1991) e Tudo sobre minha mãe.

Esse modelo de feminilidade criado por Almodóvar se imbrica na cultura espanhola de tal forma que a diluição entre o cinema e a vida social percebida na citação acima mencionada está também presente nas referências simbólicas acerca do feminino, a ponto de não se distinguir qual a influência gerada por um e outro. Para Teresa Maldonado ${ }^{2}$, a imagem das mulheres criada pelo diretor é resultado de uma mescla de elementos da tradição artística espanhola, de aspectos culturais da Espanha, das informações que ele apreendeu em seu cotidiano. Ao mesmo tempo, na medida em que essa espécie de quadro visual da mulher espanhola foi ganhando forma e se estabelecendo como um padrão em sua obra, as mulheres começam a reproduzir tais características, como uma tendência cultural. O termo "garota de Almodóvar" passa a traduzir um modelo específico de feminilidade:

[Na Espanha] Há situações em que se diz "ah, isso é de Almodóvar". Por exemplo, essa atriz que está aqui atrás de nós está como de Almodóvar, com uns gritos [Risos]. Essas mulheres assim incorporam a excentricidade que antes não existia, a mulher espanhola, assim como a classe média espanhola, era muito pacata. E, de repente, incorpora uma espécie de excentricidade que se assemelha à classe baixa espanhola, que antes não existia. Sobretudo a classe média muda completamente os estereótipos.

O estilo esperpêntico ${ }^{3}$ dos filmes de Almodóvar constrói uma imagem do feminino com uma dose exagerada dos elementos e características historicamente associados às mulheres: as chamadas "revistas do coração", o mundo dos salões de beleza, das "novelas rosas", tudo revestido de comicidade e ironia, mas que, segundo Teresa Maldonado, se baseia em uma realidade subjacente. Esse exagero, para María Antonia García de León ${ }^{4}$, e as repetições dos mesmos temas foram, aos poucos, piorando o seu cinema. Segundo a pesquisadora, em alguns filmes, como Volver, o diretor cria uma imagem estereotipada da mulher espanhola, sem a veracidade de outras películas como Que fiz eu para merecer isso? e Mulheres à beira de um ataque de nervos que, para ela, correspondem a registros autênticos da condição social das mulheres.

$\mathrm{O}$ status de verdadeiro/autêntico e de farsa que são utilizados pela pesquisadora para classificar a abordagem das mulheres no cinema de Almodóvar demonstra o quão legítimo o modelo de feminilidade construído por ele se tornou no cinema e na visão do público. O diretor é responsável pela elaboração de uma determinada subjetividade feminina que corresponde a uma imagem idealizada e ressignificada das mulheres. Nesse aspecto, Almodóvar é certamente um

\footnotetext{
2 Dados de entrevista. Pesquisa de campo realizada em Madri, em 13 nov. 2014.

3 O termo se refere ao Esperpento, gênero literário criado por Ramón del Valle-Inclán, escritor espanhol da "geração de 98", em que se deforma a realidade, ressaltando seus aspectos grotescos, e marcado por uma linguagem coloquial e uma elaboração muito pessoal, popular e emotiva (Real Academia Española, 2014).

4 Dados de entrevista. Pesquisa de campo realizada em Madri, em 3 nov. 2014.
} 
inventor de mulheres, como afirma Guillermo Infante. Em contrapartida, a projeção desse universo feminino estabelece uma oposição entre o mundo dos homens e o das mulheres, recai na estrutura assimétrica sustentada pelo discurso da diferença sexual:

O problema dos homens e das mulheres é que, pertencendo à mesma espécie e se parecendo inclusive fisicamente (os chacais também se parecem com os cachorros e não o são), não se entendem entre eles. Assim é e assim continuará sendo. No final do filme [Mulheres à beira de um ataque de nervos], uma jovem roqueira diz à Pepa que prefere as motos aos homens. Pepa lhe responde: É muito mais fácil aprender mecânica do que psicologia masculina. Uma moto se pode chegar a conhecer a fundo, um homem jamais (Almodóvar, 2011c:134).

Embora Almodóvar afirme não gostar de categorizações, ao criar um modelo de feminilidade esses filmes estabelecem atributos próprios do masculino e do feminino, divisão marcadamente fundada no pensamento da diferença. Se, por um lado, esses filmes promovem certos deslocamentos, demonstrando a pluralidade dos indivíduos e das performatividades, reside nos discursos da sua filmografia - se analisada em conjunto - uma propensão a reafirmar uma divisão polarizada entre os dois termos, como se ela sempre houvesse existido.

Essas categorias, entretanto, de acordo com Monique Wittig (2006), só fazem sentido no regime da heterossexualidade. O pensamento heterossexual produz a diferença entre os sexos e, a partir dela, organiza as relações humanas e toda a gama de conceitos que escapam à consciência. Tais processos inconscientes vão sendo fixados historicamente pelos mitos e pela proliferação de metáforas que legitimam os discursos. As categorias, portanto, não possuem sentido algum fora da heterossexualidade: sexo, diferença sexual, desejo, inconsciente, homossexualidade, homem, mulher. Quando se utiliza essas classificações já se faz referência a esse sistema.

"Homem", "mulher", "masculino" e "feminino", para a autora, são conceitos políticos de oposição, criados como diferentes para legitimar a opressão, por isso, construir a diferença é um exercício de poder. Poder que se expressa, inclusive, no ato de nomear as coisas, pois traduz uma forma de controle e de dominação sobre o Outro (Haraway, 1995). Constituídos pelos sistemas de signos que ordenam o mundo, os indivíduos, quando determinados a partir da generalização dos termos, são vistos como seres invariantes, presos em um vazio a-histórico como se fossem programados geneticamente. Além de impossibilitar o estabelecimento de outras categorias, os discursos dominantes suprimem a violência retórica contida nas diversas linguagens que estruturam o nosso campo simbólico - das quais as imagens cinematográficas fazem parte - e, por sua vez, a opressão dela resultante.

A produção de uma subjetividade feminina pelo cinema provém dessa manipulação, sendo uma maneira de configurar corpos e mentes que fortalece o mito da mulher, induz as mulheres a se reconhecerem na definição criada pelos discursos hegemônicos. Segundo Wittig, o mito da mulher é uma "marca" imposta pelo opressor sobre os oprimidos, que produz efeitos concretos nas consciências e nos corpos das mulheres. O que aparentemente consiste em uma percepção direta e natural, não passa de uma formulação discursiva fictícia derivada da interpretação de aspectos físicos. Nesse sentido, "mulheres" e "feminino", por exemplo, não precedem de seu significado, uma vez que é necessário que as mulheres sejam constituídas como tal para que sejam assim identificadas. A exaltação das mulheres pela reafirmação dos mitos consiste, assim, na eleição de algumas qualidades distintivas por eles instituídas para defini-las, e não questioná-las significa admitir as categorias políticas impostas.

Assim como Wittig, AdrienneRich (1996) compreende a heterossexualidade obrigatória como uma instituição política que exerce o controle sobre as mulheres confinando-as a um regime de opressão social (pelo matrimônio e pela maternidade) e econômica (pela exploração na divisão sexual do trabalho). Rich afirma que a heterossexualidade, não sendo uma "preferência" para as mulheres, opera como uma forma de dominação que reflete as necessidades e fantasias masculinas, ocultando as formas sociais que relegam as mulheres ao matrimônio $e$ ao amor heterossexual. A partir dessa perspectiva, Wittig e Rich defendem uma transformação política dos conceitos-chave que sustentam o sistema heterossexual, o que só seria possível mediante a supressão das categorias dela derivadas e a adoção de outras. A "existência lésbica" seria, então, uma alternativa para 
romper com o regime econômico e político controlado pelos homens porque a lésbica, ao escapar às funções socialmente impostas, negaria tanto a definição de "mulher", como toda a ordem estabelecida. De acordo com Wittig, por esse motivo as lésbicas não seriam mulheres.

As reflexões acerca do pensamento heterossexual têm como base o fato de que a sua fundação se dá pela instituição do Outro, é a demarcação da diferença o princípio essencial do estabelecimento das hierarquias de poder. Partindo dessa lógica é que Simone de Beauvoir (1970) buscou compreender o estabelecimento da hierarquia entre os sexos apontando para a produção da mulher nas sociedades e para o fato de que a feminilidade é resultado de um investimento simbólico em que a linguagem estrutura os significados do que é ser mulher. A subordinação das mulheres viria de sua inferiorização já que a categoria outro constitui o signo simbólico do pejorativo. Tal inferioridade seria necessária para manter a ordem social e o poder que a postula, sendo que a mulher ideal será a que mais conseguir se materializar no Outro.

A dicotomia masculino/feminino impregna e determina nossa visão de mundo e os modos em que vivemos nele. É um mito que parte da repartição da humanidade em duas categorias de indivíduos e, ao ser estabelecido como verdade absoluta, coloca homens e mulheres diante desses modelos, tendo sua feminilidade e masculinidade avaliadas a partir deles; os que desviam dessas idealizações se revelam como incoerências. A afirmação da alteridade se dá, assim, pela cristalização de um "eterno feminino" que se conforma por meio dos inúmeros mitos tradicionalmente associados às mulheres. Beauvoir mostra como esses mitos se constituem em uma "marca" criada em função das aspirações dos homens, se apresentando como uma condição, um destino. A mulher, assim, seria feita pelos homens no momento em que o mito da feminilidade introduz o elemento outro nas sociedades.

A idealização da feminilidade ganha diferentes contornos na medida em que os mitos vão sendo repaginados pelas relações sociais e suas práticas. O cinema como uma linguagem, um gerador simbólico da realidade, não raramente, reelabora esses mitos, (re)estabelecendo categorias opostas para demarcar a diferença e enfatizar os modelos de feminilidade: a virgem e a promíscua/vamp/femme fatale, a santa e a pecadora, a mulher casada/viúva/mãe e a solteira, entre outras. O cinema de Almodóvar consegue desassociar a figura da mulher da moral religiosa (a ameaça do pecado) e de algumas convenções sociais (a mulher pura, virtuosa, recatada), o que o afasta da tradição cultural da Espanha, em que a sensualidade e o desejo carnal iam de encontro à censura e à contenção, expressa em obras clássicas, como as de Frederico García Lorca, Ramón Del Valle-Inclán e Luis Buñuel.

Almodóvar dota as mulheres de um destino próprio, não restringindo as personagens femininas em função dos homens, lhes confere autonomia e poder de decisão para se realizarem, "seu único problema será conquistar, em um mundo medíocre, um destino feito sob medida" (Beauvoir, 1970:293). Mas, embora o diretor afirme suspender as categorizações e tratar os personagens como seres humanos, o feminino e o masculino não se encontram exatamente em pé de igualdade porque há sempre uma retórica implícita em seus filmes que reafirma - muitas vezes pela repaginação de alguns mitos - a soberania do masculino. A dependência afetiva das mulheres em relação aos homens e a realimentação da histeria, da loucura feminina, a construção das mulheres como manipuladoras por meio da capacidade de fingir e mentir para sobreviver, a maior aptidão para manter laços afetivos, representada pela solidariedade feminina, a recorrência da violação das mulheres, muitas vezes naturalizada, suavizada ou ridicularizada na construção visual, $e$ a passividade do feminino em relação à vivência do desejo sexual são alguns dos discursos utilizados no conjunto de sua filmografia.

\section{A repaginação dos mitos: os (contra)discursos na produção da subjetividade feminina}

A construção de uma imagem mítica das mulheres pode ser vista em Fale com ela. Nesse filme, Benigno é um enfermeiro que cuida de uma paciente em coma, a bailarina Alicia, por quem a história posteriormente revelará que é apaixonado. No mesmo hospital, o enfermeiro constrói uma amizade com o jornalista Marco, namorado da toureira Lydia, que também entra em coma após um acidente em uma tourada. As personagens femininas são retratadas como fonte de contemplação e, embora estejam na maior parte do tempo imóveis em uma cama de hospital, 
suscitam o desejo masculino e despertam uma série de sentimentos nos homens. Na personagem Alicia esse discurso é mais eloquente, já que é ela quem desperta o desejo de Benigno. São os homens que conduzem a vida das duas mulheres em coma. A referência ao espetáculo Café Müller, de Pina Bausch, na abertura do filme alude a essa ideia:

Quando terminei de escrever Fale com ela e voltei a olhar o rosto de Pina [Bausch], com os olhos fechados, vestida com uma exígua combinação, os braços e as mãos estendidas, rodeada de obstáculos (mesas e cadeiras de madeira), não tive dúvida de que essa era a imagem que melhor representava o limbo que habitavam as protagonistas da minha história. Duas mulheres em coma que, apesar de sua aparente passividade, provocam nos homens o mesmo prazer, a mesma tensão, paixão, ciúmes, desejos e desilusão do que se estivessem de pé, com os olhos abertos e falando feito papagaio (Almodóvar, 2011a:275).

No espetáculo, duas mulheres sonâmbulas se movimentam pelo palco enquanto um homem antecipa os seus passos retirando as mesas e cadeiras do caminho para que elas não se choquem contra os móveis. O homem desperto pode representar o enfermeiro Benigno que, após o coma de Alicia, mergulha em seu mundo, passando a frequentar os lugares e a fazer tudo que ela gostava como ver filmes mudos e peças teatrais - para depois lhe descrever a experiência. Benigno é o corpo e os olhos de Alicia, é o seu elo com a realidade, quem a mantém viva e vai retirá-la, ainda que de forma violenta, do limbo em que se encontra.

O corpo de Alicia é, durante todo o filme, contemplado pelos homens; primeiro por Benigno,que a observa durante a aula de balé na companhia de dança em frente à sua casa; depois por Marco, que a admira pela fresta da porta ou mesmo dentro do quarto do hospital quando ela, em coma, está seminua na cama. Há, ainda, outra forma de contemplação de Alicia, personificada pelo olhar da câmera, nos inúmeros planos do corpo inerte da paciente na cama do hospital.

O coma de Alicia transpõe para ela uma atmosfera misteriosa porque o filme pouco revela sobre sua vida e personalidade, que nos é contada praticamente sob o ponto de vista de Benigno. Na cena em que Alicia e Lydia são levadas por Benigno e Marco para um banho de sol na varanda do quarto, os rostos das duas se movem involuntariamente como se estivessem conversando entre elas. O enfermeiro observa e diz que elas parecem falar dos dois. Em seguida, pergunta o que elas estariam conversando, já que "as mulheres contam tudo umas para as outras". A cena alude à polaridade entre o universo feminino e o masculino colocando-os como domínios impenetráveis pelo sexo oposto. O mistério e a impossibilidade de os dois descobrirem o tema da "conversa" não seria, pela fala de Benigno, devido ao estado de coma, mas sim por se tratar de uma linguagem que eles não entendem porque é própria das mulheres.

Para Beauvoir (1970), a compreensão da mulher como mistério surge da impossibilidade dos homens de adentrar a sua experiência singular; o prazer erótico da mulher, os incômodos da menstruação, as dores do parto que são por eles ignorados. A reciprocidade, assim, se traduz no mistério, já que, sendo o masculino tomado como universal, as categorias por meio das quais os homens interpretam e organizam o mundo são consideradas por eles como absolutas. Sem reconhecer a reciprocidade, portanto, as mulheres são vistas como um mistério impenetrável e de natureza enigmática.

A violação de Alicia, cometida por Benigno, é ocultada do espectador e contada por meio da metáfora do Amante minguante, filme mudo criado por Almodóvar para esconder o ato. Enquanto no discurso explícito a sequência é elaborada para significar o estupro, a construção visual engendra um contradiscurso que opera como inversão simbólica do que se pretende mostrar. $\mathrm{Na}$ cena, Benigno, após ter ido à Filmoteca Española assistir à projeção, narra a história para Alicia enquanto massageia o seu corpo. Na película, Amparo, cientista, trabalha na criação de uma fórmula de emagrecimento, quando seu amante, Alfredo, como prova de amor, ingere a porção nunca testada em seres humanos. Como efeito, ele míngua gradativamente tornando-se um homem diminuto. Para que Amparo não o veja naquele estado, Alfredo se refugia na casa da mãe até o dia em que a cientista o descobre e o leva com ela. À noite, em um quarto de hotel, Amparo dorme, e o amante minguante passeia pelo seu corpo em direção à vagina, introduzindo partes de seu corpo até entrar por completo e permanecer para sempre dentro da amada. 
A imersão de Alfredo na vagina de Amparo simboliza o ato da penetração de Benigno em Alicia e, consequentemente, a afirmação da superioridade do enfermeiro sobre a paciente. $\mathrm{O}$ que se vê diante da câmera, entretanto, é o inverso: Alfredo, diminuto, vulnerável e impotente é "engolido" pela imensa cavidade vaginal em que fica retido eternamente. A violência de Benigno é, assim, ressignificada e ele é transformado, no discurso implícito da trama, em vítima. A vagina surrealista de tamanho descomunal construída por Almodóvar é a figuração da mulher devoradora e da ameaça que ela representa por seduzir e despertar o desejo incontrolável dos homens, que é o que ocorre no processo de culpabilização das vítimas de violência sexual. Não por acaso o diretor constrói uma vagina cênica de grandes proporções para filmar a sequência. Após a violação, Alicia engravida e desperta do coma, o que, simbolicamente, traduz outra inversão, já que é Benigno quem possui o poder de gerar vida ao retirá-la do estado vegetativo em que se encontrava, uma espécie de revisitação do conto $A$ bela adormecida.

O mesmo ocorre com Robert Ledgard em A pele que habito (2011). O personagem é uma releitura da figura do criador nos diversos mitos de origem disseminados ao longo da história. Cirurgião renomado, Robert trabalha na criação de uma pele artificial que seja resistente a qualquer tipo de atrito. Após o estupro de sua filha por Vicente, ele rapta o rapaz e, como vingança, o utiliza como cobaia de seus experimentos. O médico, então, cria uma mulher sob sua medida ao realizar forçadamente uma transgenitalização em Vicente; mais uma vez, como reiteradamente se apresenta nos mitos, é o masculino que engendra o feminino, Vicente é uma espécie de Adão moderno, cujo corpo dá origem ao seu duplo assimétrico. Robert é a encarnação do Deus criador, tal qual Pigmaleão esculpindo Galatea, ou mesmo a reinvenção da natureza pela ciência tão explorada pelo cinema, como em Frankenstein (1931), de James Whale e Os olhos sem rosto (1960), de Georges Franju, duas inspirações de Almodóvar na elaboração do roteiro de seu filme (Almodóvar, 2011b).

O poder criador do homem sobre a mulher é evocado na sequência 138 do roteiro de A pele que habito:

As mãos do doutor Ledgard lhe retiram a máscara asséptica do rosto. Debaixo se revela um belo rosto de mulher, com os cabelos bastante curtos, cresceram cerca de um centímetro. Vicente abre os olhos. Dr. Ledgard: 'Não posso continuar te chamando de Vicente. A partir de agora você se chamará Vera'. O homem batiza a sua obra com um nome que transmite autenticidade (Almodóvar, 2012:118).

A referência ao batismo de Vera condiz com a transfiguração do corpo masculino para o feminino (o homem cria a mulher), mas também assevera a supremacia do cientista criador; o ato de nomear a sua obra é, antes de tudo, um exercício de poder. A reprodução dos mitos de origem, em que a capacidade de gerar vida é invertida, e são os homens os seres que engendram as mulheres, desvela a relação assimétrica entre os sexos no plano da reprodução, sendo elas que detêm o privilégio de originar tanto o idêntico, como o diferente, conforme discute Françoise Héritier (1996). Um plano do filme é bastante representativo dessa inversão simbólica: Vê-se Robert Ledgard, inclinado sobre o corpo de Vicente/Vera, que jaz imóvel sobre uma mesa cirúrgica; o cirurgião dá os últimos retoques em sua obra.

Almodóvar afirma que A pele que habito é uma história sobre vingança: a mudança de sexo forçada a que Vicente é submetido, motivada pela ira de Robert pelo estupro de sua filha. Garzo (2011), em sua apreciação crítica do filme, comenta que o experimento que o cirurgião realiza com o corpo de Vicente é um dos atos mais sinistros da história do cinema. Obviamente, o procedimento realizado contra a vontade do rapaz constitui uma violência aterradora. Levar em conta, porém, o que representa essa violência nos permite questionar os fundamentos dessa interpretação. $\mathrm{O}$ ato visto como impiedoso é a mudança de sexo não consentida de um jovem heterossexual, satisfeito com o seu sexo e com a sua identidade de gênero. Ao ser submetido à transgenitalização contra a sua vontade, ele é compelido não apenas a viver com outro corpo, como também a incorporar um gênero que lhe foi imposto.

Por outro lado, a vingança ou o castigo em jogo, consiste na transformação de Vicente em uma mulher, retirando-lhe a virilidade e o poder para convertê-lo no Outro, relegando-o a uma posição inferior na hierarquia sexual. É a partir desse deslocamento, portanto, que Vicente passa de 
violador à vítima, do ser que penetra ao que é penetrado/violado, uma espécie de ritual de iniciação da mulher, como demonstra emblematicamente a cena em que Robert exibe os dilatadores em diversos tamanhos, que ele precisa introduzir para a conformação do orifício vaginal. Tempos depois, assim como Benigno devolve Alicia à vida por meio do ato sexual, o nascimento da "nova mulher" em A pele que habito ocorre pela violação cometida contra Vera pelo personagem Zeca e por sua relação sexual com Robert.

A mudança de posição gerada pela transformação física de Vicente implica também na associação de Vera aos modelos de feminilidade: Assim como Pigmaleão se apaixona por Galatea, Robert se vê apaixonado por sua criação, e Vera é retratada como a mulher manipuladora, capaz de fingir e atuar para sobreviver, se aproveitando do sentimento que o cirurgião nutre por ela. Em alguns momentos, o filme a constrói como uma ameaça, tal qual se observa na explicação de Almodóvar:

\begin{abstract}
As câmeras estão presentes na vida de Vera, como estão na vida atual das pessoas. Além de mostrá-la como um animal cativo, dependendo de seu tamanho em relação ao quadro, a imagem de Vera nas telas atribui à narração uma informação sutil e significativa. Por exemplo, quando o Homem Tigre a descobre nas telas da cozinha, Vera está fazendo yoga com uma bola de borracha (das que se utilizam em academias de ginástica). Seu tamanho na tela é insignificante. Especialmente quando o Homem Tigre entra no quadro e aproxima seu rosto da tela, dá a impressão de que poderia comer Vera (é o que tentará nas sequências posteriores). A relação de forças lembra as da loira por quem King Kong se apaixona e o gigantesco gorila. Entretanto, quando Robert entra em seu quarto e liga o monitor através do qual vê todo o quarto de Vera com a cama no meio, a primeira coisa que chama a atenção é o tamanho do plasma; centrado na parede, a tela se converte em uma espécie de parede transparente. Quando Robert se aproxima da chaisselongue, situada em frente à tela, e dá zoom sobre a imagem de Vera até só ver o seu rosto, o rosto de Vera é descomunal, gigantesco, comparado ao corpo de Robert ou às dimensões do próprio quarto. O rosto de Vera domina o quarto e, sem dúvida, o seu morador, embora ele seja o último a se dar conta disso. Nesses momentos de estreita e íntima vigilância, ainda que Vera seja a vítima, do seu rosto desmesurado emana um poder muito superior ao ostentado pelo do doutor Robert, que a contempla extasiado. É ela que parece vigiar o cirurgião, e não o contrário. É ela a que transmite a impressão de que poderia devorá-lo se ele lhe propusesse (Almodóvar, 2011b:380-382).
\end{abstract}

A fala revela a ambivalência construída imageticamente para indicar o deslocamento de posição da personagem. Ora vítima de Zeca, o homem disfarçado de tigre, Vera é enquadrada em plongé pelo monitor da cozinha, em sua pequenez e impotência diante da voracidade de seu agressor. Em contrapartida, enquadrada no monitor da parede do quarto de Robert, Vera se agiganta, encara a câmera com um olhar desafiador, representando a ameaça do desejo desmesurado do cirurgião, como um monstro que, fabricado e alimentado pelo cientista-criador, se volta contra ele.

A contemplação da beleza feminina, se já existia em Fale com ela, é extremada em A pele que habito. $\mathrm{O}$ monitor permite ao cirurgião admirar - mas também controlar - a sua obra como quem contempla um quadro. As referências às obras de Ticiano, com a presença de duas de suas pinturas de temas mitológicos, Vênus de Urbino (1538) e Vênus e o organista (1548-1549) no corredor entre os quartos de Robert e Vera enfatizam o prazer voyeurístico do corpo feminino. No quarto do cirurgião, vê-se uma pintura do artista espanhol Guillermo Pérez-Villalta, Dionisosencuentra a Ariadna em Naxos (2008). O quadro apresenta traços da obra de Ticiano - o tema mitológico, o colorido e a composição - e retrata o momento em que o deus Dionísio encontra Ariadna, filha de Minos e Pasífae, na ilha de Naxos, depois de ser abandonada por Teseo, a quem planejou derrotar para conseguir sair do labirinto em que estava confinada. Dionísio, assim, a encontra adormecida e lhe converte em sua esposa (Terán, 2011). A tela aparece ao fundo, atrás de Robert e, à frente, a câmera enfoca o monitor com a imagem de Vera, acentuando a analogia ao discurso da criação. A posição em que Vera se deita na cama em seu quarto forma um quadro com a mesma composição das pinturas de Ticiano. 
Mais adiante, a cena do quadro se materializa quando Vera está na cozinha preparando o café da manhã junto com Marilia. No roteiro, Almodóvar afirma que a mudança no traje da personagem, do body para um camisão de Robert, representa a mudança de status de Vera na casa, assim como a transformação de sua relação com o médico. Robert, o "Dionísio moderno", converteu Vera em sua "esposa", como expressa a obra de Pérez-Villalta. A ideia da criação da mulher pelo homem é também enfatizada por Almodóvar quando ele se refere ao diretor de cinema como um criador de mulheres. Assim como Robert fabrica Vera e projeta nela as suas aspirações $e$ fantasias, Almodóvar vê o diretor de cinema como aquele que transforma as atrizes na figura feminina desejada:

E em relação ao mago do suspense, é muito difícil subtrair a influência de Hitschcock e de Vértigo, especificamente. Em Abraços partidos, quando o diretor Mateo Blanco dirige Lena com um sussurro nas provas de maquiagem e cabelo, está criando uma nova mulher para seu próprio prazer e, para que Lena possa fugir de sua vida calamitosa e se refugiar nessa nova mulher, ele lhe propõe o personagem de Pina. Aí já estava Vértigo e James Stewart se encarregando do estilismo, a cor do cabelo, o penteado, a roupa de Kim Novak, até convertê-la na mulher morta que tanto amou. Quando vejo Stewart rejeitando trajes em uma loja de moda e a funcionária lhe dizendo: 'já vejo que o senhor sabe muito bem o que quer', vejo a mim mesmo, decidindo e provando nas atrizes os vestidos que lhes ajudarão a se converter em 'outra mulher' para mim. James Stewart representa a figura do diretor (Almodóvar, 2011b:382-384).

Tanto a criação da mulher como objeto de desejo e contemplação, como a encarnação da fantasia da "mulher artificial perfeita" para o diretor, definem o masculino como o ser transcendente $e$ transformador. A libertação de Vera nas cenas finais pode remeter tanto à desvinculação da autoridade do criador, em que a criatura conquista a autonomia para seguir redefinindo-se de acordo com suas próprias aspirações, como também a reiteração do mito de Pigmaleão, em que, apaixonado por sua obra, é finalmente dominado e destruído por ela.

O fato de Almodóvar ser conhecido em sua trajetória como um "diretor de atrizes" é confundido, muitas vezes, com uma suposta subjetividade feminina e habilidade do diretor de falar como e pelas mulheres. É necessário, entretanto, que se tome um distanciamento crítico desses filmes, questionando se o fato de dar maior visibilidade às personagens femininas, por si só, implica no posicionamento das mulheres como sujeitos, e na priorização de sua experiência no universo filmico. Há que se considerar, sem dúvida, o deslocamento que o cinema de Almodóvar opera em relação à narrativa convencional, dotando as personagens femininas de características atribuídas, geralmente, aos homens, e vice-versa. A centralidade das mulheres em muitas de suas produções também privilegia essas personagens como protagonistas das ações, retirando-as da passividade $e$ da dependência da ação masculina.

Ao mesmo tempo, é no que se refere ao desejo sexual que, como um contradiscurso, a diferença sexual se impõe na construção dos termos da linguagem visual, colocando-o como um domínio masculino. Uma análise da filmografia de Almodóvar permite verificar que, no sentido sexual, o masculino é predominantemente o ser que deseja, é constituído como o sujeito do desejo. Há, nesses filmes, uma diferenciação nos significados, nos tipos de desejo e na maneira como ele se manifesta quando é abordado no feminino e no masculino ${ }^{5}$.

O desejo que corresponde ao feminino se associa a uma vontade de liberdade, de autonomia sobre as suas escolhas e condutas, de domínio sobre o próprio corpo, os seus usos e prazeres; as personagens femininas de Almodóvar querem ser - e são - donas de seu destino. Em relação ao desejo especificamente sexual, entretanto, nas personagens femininas ele é, na maioria das vezes, canalizado para o amor-paixão, para a dependência afetiva do ser amado, além da dor e da desilusão - expressadas, geralmente, pela histeria e pelo descontrole emocional -, decorrentes do abandono. $\mathrm{O}$ abandono por parte de quem se ama - que pode ser tanto homens, quanto mulheres - é um dos principais dramas das personagens femininas do diretor.

\footnotetext{
5 Uma discussão mais aprofundada sobre a construção do desejo sexual no cinema de Almodóvar pode ser vista em Silva (2016).
} 
Quando o feminino de fato é construído como sujeito do desejo, as personagens são apresentadas de maneira exótica, na fronteira da abjeção. Embora não sejam julgadas moralmente por suas ações, no momento em que esse desejo se manifesta ativamente há um contradiscurso simbólico que as investe de uma estranheza, dando a impressão de que elas se apropriam de um lugar e de algo que não lhes pertence. É o caso, por exemplo, da personagem Sexilla, em Labirinto de paixões (1982) e Chon, no curta A vereadora antropófaga, integrado aos extras de Abraços partidos (2009).

A complexidade dessas imagens e discursos expõe a ambivalência dos significados textuais de uma produção cultural. Sendo o cinema uma forma simbólica de contar histórias e de tornar inteligíveis as experiências e os códigos sociais que se configuram no espaço narrativo, é um ato constante de negociação de identidades, discursos, valores, de poder e de posições. Segundo Judith Butler (2002), a fantasia do cineasta é a crença em seu poder de transformar o que registra. Almodóvar, ao se colocar como um criador que, diante da câmera, transforma as atrizes nas mulheres desejadas, atribui a si mesmo o poder de conferir essa feminilidade, de "batizar" essas mulheres conforme um modelo. A câmera, por sua vez, produz e legitima as mulheres que o diretor cria, sendo também um instrumento de poder, pois assume o olhar corporizado do privilégio masculino, controlando o campo de significação. Como discursos às avessas algumas imagens estereotipadas de homens e mulheres são denunciadas pelas dissonâncias que se manifestam nas zonas do invisível e do indizível, e pela própria linguagem cinematográfica, pelos recursos técnicos e estratégias de filmagem, que escapam muitas vezes às intenções do diretor.

\section{Considerações finais}

Em um artigo publicado no dia 31 de outubro de 2015, no jornal El País, intitulado Trabajar conmigo, Pedro Almodóvar "ensina" o que se deve ter ou fazer para ser una chica Almodóvar. Como o título sugere, trata-se de atributos que o diretor aprecia nas mulheres que encarnam frequentemente as suas personagens, muitas delas lançadas ou promovidas por ele, pois, desde que logrou o sucesso internacional, atuar em suas produções passou a ser a aspiração de muitas atrizes. No mesmo dia, também foi publicado no El País um artigo assinado pela crítica Elvira Lindo, intitulado Ser una chica Almodóvar, em que ela fala sobre o significado dessa expressão para a geração dos anos 1980, época em que o diretor debuta no cinema, e a maneira como as mulheres espanholas incorporaram as características das personagens que o diretor popularizou ao longo de sua carreira. $\mathrm{O}$ artigo termina com a frase "Obrigada, Pedro, por sua parcela de contribuição na conquista de nossa liberdade".

Os dois artigos são reveladores da construção imagética e discursiva em torno de Almodóvar como um "diretor de mulheres": Essa marca lhe confere o poder de manejar alguns repertórios simbólicos e veículos de significação social que validam não apenas determinado modelo de feminilidade, mas o conceito do que é ser mulher em um contexto específico. Ser uma garota de Almodóvar remete a uma subjetividade feminina cristalizada pelos discursos dos filmes, da imprensa, do próprio cineasta, que foi capaz de perceber e incorporar essa imagem a ponto de deixar suas personagens cada vez mais sofisticadas ao longo dos anos. Aos poucos, foi revestindoas de um glamour aos moldes de Hollywood, criando o seu star system particular, e reproduzindo a tendência que ele conheceu primeiramente com os cromos e, mais tarde, nas telas.

A frase que conclui o artigo de Elvira Lindo, porém, acrescenta mais um dado a esse fenômeno: a referência a Almodóvar como colaborador em um quadro de transformação social na abertura democrática da Espanha, em que se verifica uma mudança de costumes entre a juventude $e$, principalmente, entre as mulheres. Seus filmes veicularam uma nova imagem $e$ novos significados do "feminino", com a valorização da autonomia, da liberdade sexual, de ação e de pensamento, a ausência de preconceitos e julgamentos morais, além de um modo de falar, de caminhar, de se vestir e de se portar muito característicos da cultura de rua madrilenha.

Este artigo pretendeu demonstrar, entretanto, que uma análise mais ampla de sua filmografia permite compreender as diversas camadas de significados que compõem a narrativa almodovariana, constituída, muitas vezes, por tensões, por discursos contraditórios e instáveis, um emaranhado simbólico que denuncia a complexidade de se definir uma obra que, de modo algum, 
se esgota em uma única interpretação. Tentou-se, assim, problematizar a perspectiva do diretor nos filmes analisados, pensando no significado da legitimidade que eles assumem perante o público ou, como questiona Merri Torras, em sua leitura de Gayatri Spivak, "que serviço prestamos ao poder hegemônico falando como representantes paradigmáticos de uma categoria concreta, reivindicando essa diferença e autoconscientes do que reproduzimos ou corremos o risco de reproduzir com ela?" (Torras, 2000:138).

Tal como atesta Annie Leclerc (1977), escrever, ter o domínio da palavra, é um ato de poder, um privilégio. O cineasta, como criador, ocupa a posição privilegiada de (re)significar ao falar sobre, ainda que não assuma nenhum compromisso político, como Almodóvar costuma afirmar. O teor político, porém, é inerente a toda produção cultural, uma vez que produzir discursos e expressá-los por uma estética específica é reformular as experiências a partir da elaboração de novas formas de sentir e de conceber o mundo, engendrando novas subjetividades políticas. O fazer cinematográfico é um ato estético e também político, na medida em que permite ao realizador dispor de lugares privilegiados de fala, controlando, em parte, o que se vê e o que se pode dizer sobre o que é visto (Rancière, 2005).

Desse modo, o reconhecimento de Almodóvar como "diretor de mulheres", em que falar sobre muitas vezes se confunde com o falar por, suscita algumas reflexões, como se existiria, assim, uma estética ou um olhar feminino particular, ou o que converteria um texto em um discurso feminino? O tema? $\mathrm{O}(\mathrm{a})$ autor(a)? Só o fato de falar sobre mulheres ou retratá-las dando maior protagonismo e visibilidade já implica em falar como mulher? Como questiona Leclerc, haveria uma palavra que pudesse descrever ou expressar conjuntamente as experiências dos corpos femininos?

Ao que parece, Almodóvar não questiona a si mesmo como um homem que "representa" as mulheres, não se opõe ao seu próprio privilégio de um homem que fala da condição feminina. Apesar da centralidade das mulheres em muitos de seus filmes, o feminino parece muito mais como uma temática do que como a proposta de uma nova linguagem do desejo que se aproprie da cultura dominante para transpor os termos da dominação. A subversão ocorre quando os discursos hegemônicos são recriados em outros parâmetros, e não quando, ainda que deslocados alguns padrões, permanecem a eles subordinados. Se, de acordo com Merri Toras (2000), a linguagem estrutura a realidade e, a partir dela, se conformam todos os mundos possíveis, uma mudança nos padrões visuais do cinema implica na reelaboração da linguagem do desejo.

\section{Referências bibliográficas}

ALMODÓVAR, Pedro. La piel que habito (guión). Barcelona, Editorial Anagrama, 2012.

ALMODÓVAR, Pedro. Sobre la película Hable con ella. In: DUNCAN, P.; PEIRÓ, B. (ed.). Los archivos de Pedro Almodóvar: el hombre de La Mancha. Colônia, Taschen, 2011a, pp.272-289.

ALMODÓVAR, Pedro. Sobre la película La piel que habito. In: DUNCAN, P.; PEIRÓ, B. (ed.). Los archivos de Pedro Almodóvar: el hombre de La Mancha. Colônia, Taschen, 2011b, pp.377-391.

ALMODÓVAR, Pedro. Sobre la película Mujeres al borde de un ataque de nervios. In: DUNCAN, P.; PEIRÓ, B. (ed.). Los archivos de Pedro Almodóvar: el hombre de La Mancha. Colônia, Taschen, 2011c, pp.126138.

ALMODÓVAR, Pedro. Sobre la película Todo sobre mi madre. In: DUNCAN, P.; PEIRÓ, B. (ed.). Los archivos de Pedro Almodóvar: el hombre de La Mancha. Colônia, Taschen, 2011d, pp.252-263.

BEAUVOIR, Simone. O segundo sexo: fatos e mitos. Vol. 1. São Paulo, Difusão Europeia do Livro, 1970.

BUTLER, Judith. Cuerpos que importan: sobre los límites materiales y discursivos del "sexo". Buenos Aires, Paidós, 2002.

CAÑIZAL, Eduardo Peñuela (org.). Urdidura de sigilos: ensaios sobre o cinema de Almodóvar. São Paulo, Annablume/ECA-USP, 1996.

EL ARTE en el cine: Almódovar y La piel que habito. [S.1.]: Cine en conserva, 2014 [http://www.cineenconserva.com/2014/05/el-arte-en-el-cine-almodovar-y-la-piel.html - acesso em 18 jan. 2016]. 
GARZO, Gustavo Martín. La búsqueda de la maravilla.In: DUNCAN, P.; PEIRÓ, B. (ed.). Los archivos de Pedro Almodóvar: el hombre de La Mancha. Colônia, Taschen, 2011, pp.269-273.

HARAWAY, Donna. Ciencia, cyborgs y mujeres: la reinvención de la naturaleza. Madrid, Ediciones Cátedra, S. A, 1995.

HÉRITIER, Françoise. Masculino feminino: o pensamento da diferença. Lisboa, Instituto Piaget, 1996.

HIDALGO, João Eduardo. O cinema de Pedro Almodóvar Caballero. Tese (Doutorado em Ciências da Comunicação), USP, 2007.

LECLERC, Annie. Palabra de mujer. Buenos Aires, Editorial La Aurora, 1977.

PEDRO Almodóvar. Box Office Mojo [http://boxofficemojo.com/people/chart/?id=pedroalmodovar.htm acesso em 01 fev. 2013].

PEDRO Almodóvar. The Internet Movie Database [http://www.imdb.com/name/nm0000264/ - acesso em 01 fev. 2013b].

RANCIÈRE, Jacques. A partilha do sensível: estética e política. São Paulo, EXO experimental (org.); Ed. 34, 2005.

$\mathrm{RICH}$, Adrienne. Heterosexualidad obligatoria y existencia lesbiana. DUODA Revista d'Estudis Feministes [10], Barcelona, 1996, pp.15-45.

REAL Academia Española. Esperpento. Diccionario de la Real Academia Española(DRAE) [http://lema.rae.es/drae/?val = esperpento - acesso em: 30 out. 2014].

RODA Viva. São Paulo, TV Cultura, Fundação Padre Anchieta, 1995. DVD Rip (94 min.): son., color.

SILVA, Paloma Ferreira Coelho. A lei do desejo: as relações de gênero no cinema de Pedro Almodóvar. Tese (Doutorado em Ciências Sociais), PUC Minas, 2016.

STRAUSS, Frédéric. Conversas com Almodóvar. Rio de Janeiro, Jorge Zahar Ed., 2008.

TERÁN, Shus. Un cuadro de Pérez Villalta en la última película de Pedro Almodóvar. EuropaSur, 2011. [http://www.europasur.es/article/ocio/1136184/cuadro/perez/villalta/la/ultima/pelicula/pedro/almodovar.htm 1 - acesso em 10 ago. 2015].

TORRAS, Meri. Feminismo y crítica lesbiana: ¿Una identidad diferente? In: SEGARRA, Marta; CARABÍ, Àngels (ed.). Feminismo y crítica literária. Barcelona, Icaria, 2000, pp.121-141.

WITTIG, Monique. El pensamiento heterosexual y otros ensayos. Barcelona, Editorial EGALES S.L., 2006. 